Revue Gouvernance

Governance Review

GOUVERNANCE

GOV ERN/ANG Eme

\title{
Zambia: Governance and Natural Resources
}

\section{Karolina Werner}

Volume 13, numéro 2, 2016

URI : https://id.erudit.org/iderudit/1039239ar

DOI : https://doi.org/10.7202/1039239ar

Aller au sommaire du numéro

\section{Éditeur(s)}

Centre d'études en gouvernance de l'Université d'Ottawa

ISSN

1912-0362 (numérique)

Découvrir la revue

Citer cet article

Werner, K. (2016). Zambia: Governance and Natural Resources. Revue Gouvernance / Governance Review, 13(2), 32-52.

https://doi.org/10.7202/1039239ar
Résumé de l'article

Cet article analyse le cadre de gouvernance des ressources naturelles en Zambie. La recherche est le résultat d'un projet plus vaste sur la gouvernance des ressources naturelles comprenant des entretiens réalisés dans un certain nombre de pays d'Afrique subsaharienne. Ce papier vise à d'identifier les lacunes et les incohérences dans la politique zambienne en matière de ressources naturelles dans le but d'élargir la compréhension de la rationalisation et de l'optimisation de la gouvernance dans ce secteur. Il propose également des suggestions sur la façon dont d'autres secteurs, tels que l'éducation, peuvent être essentiels à l'élaboration d'un cadre plus performant en matière de ressources naturelles. Le document se concentre sur la Zambie en tant que pays avec une longue histoire de l'exploitation minière et un environnement politique relativement stable, mais où subsistent des tensions entre le gouvernement et le secteur privé et où les politiques d'extraction des ressources naturelles ont été particulièrement instables ces dernières années. d'utilisation que vous pouvez consulter en ligne.

https://apropos.erudit.org/fr/usagers/politique-dutilisation/ 


\title{
Zambia: Governance and Natural Resources
}

\author{
By Karolina Werner ${ }^{12}$
}

\begin{abstract}
This paper analyzes the natural resources governance framework in Zambia. The research is the result of a broader project on natural resource governance with interviews performed in a number of countries in sub-Saharan Africa. The goal of the paper is to identify the gaps and inconsistencies within the Zambian natural resource policy framework, in an effort to broaden the understanding of how governance of the sector may be streamlined and optimized. It further offers suggestions on how other sectors, such as education, may be central to the development of a more successful natural resource framework. The paper focuses on Zambia as a country with a long history of mining and a relatively stable political environment, yet one in which tensions between government and the private sector remain, and policies on natural resource extraction which have been particularly volatile in recent years.
\end{abstract}

Keywords: Natural resources, Governance, Zambia

\section{Résumé}

Cet article analyse le cadre de gouvernance des ressources naturelles en Zambie. La recherche est le résultat d'un projet plus vaste sur la gouvernance des ressources naturelles comprenant des entretiens réalisés dans un certain nombre de pays d'Afrique subsaharienne. Ce papier vise à d'identifier les lacunes et les incohérences dans la politique zambienne en matière de ressources naturelles dans le but d'élargir la compréhension de la rationalisation et de l'optimisation de la gouvernance dans ce secteur. Il propose également des suggestions sur la façon dont d'autres secteurs, tels que l'éducation, peuvent être essentiels à l'élaboration d'un cadre plus performant en matière de ressources naturelles. Le document se concentre sur la Zambie en tant que pays avec une longue histoire de l'exploitation minière et un environnement politique relativement stable, mais où subsistent des tensions entre le gouvernement et le secteur privé et où les politiques d'extraction des ressources naturelles ont été particulièrement instables ces dernières années.

Mots clés: Ressources naturelles, Gouvernance, Zambie 
Governance is a complex term which encompasses a large variety of processes related to governing. When studying a state government, it is difficult to truly capture the broader direction and actions of the government without taking an in-depth look at the various sectors it is comprised of. These sectors of governance, help assess the linkages, both positive and negative, in a network of policies and regulations that are representative of the state's government.

This paper focuses on one such sector in Zambia, analyzing natural resources governance. The research is the result of a broader project on natural resource governance with interviews performed in a number of countries in sub-Saharan Africa. The goal of the paper is to identify the gaps and inconsistencies within the Zambian natural resource policy framework, in an effort to broaden the understanding of how the governance of the sector may be streamlined and optimized. It further offers suggestions on how other sectors, such as education, may be central to the development of a more successful natural resource framework. The paper focuses on Zambia as a country with a long history of mining and a relatively stable political environment, yet one in which tensions between government and the private sector remain, and policies on natural resource extraction which have been particularly volatile in recent years.

\section{History of Zambian Mining}

Zambia has a long history of mining which began under colonial rule in the 1920s when South African and American companies (Rhodesian Selection Trust and Anglo-American Corporation $^{1}$ ) invested in the first commercial copper mines in Northern Rhodesia. At the time Northern Rhodesia was seen primarily as a source of minerals to support the more industrially, socially, and educationally developed Southern Rhodesia (present Zimbabwe) Fraser and Lungu, 2007). This division was set up by the British colonial powers which populated the more fertile southern region, using the northern areas almost exclusively to serve their commercial interests.

When Zambia became independent in 1964 the five main copper mines owned by Rhodesian Selection Trust and Anglo-American Corporation were contributing over 50 percent of government revenue (Kruger, 2013). Due to the success of the copper mines, the Copperbelt province was transformed into a vibrant urban and industrial community. In 1969 Zambia was classified as a middle-income country, with one of the

\footnotetext{
${ }^{1}$ The Rhodesian Selection Trust (later known as the Roan Selection Trust) and Rhodesian Anglo American Corporation were the two main copper producing companies in Zambia. Five mines were owned by these investors: Mufulira, Nkana, Nchanga, Konkola, and Luanshya. The mines brought on the development of five major towns in Zambia-Chiliabombwe, Kitwe, Chingola, Mufulira, and Luanshya (Limitlaw, 2011).
} 
highest GDP in Africa (\$476 per capita, compared to Zimbabwe with $\$ 347$ per capita (World Bank, 2015b)), largely due to the growth of the mining sector (responsible for 41 percent of GDP in 1965, slightly down to 33 percent in 1969 (Central Statistical Office, 2014)) and the linkages it promoted encouraging the development of construction, engineering, and financial sector firms among others (Fraser and Lungu, 2007).

However, in 1968 President Kenneth Kaunda announced that the mines would be nationalized, following a disagreement over the lack of new investment and the royalty system (5 percent) with the two mining companies. Kaunda argued that the companies were not investing in the mines sufficiently, while the foreign investors argued that the royalties were prohibitive and were hampering further investment (Fraser and Lungu, 2007)2. In 1973 Zambia's copper mines were nationalized and the Zambian Consolidated Copper Mines (ZCCM) took over from private investors. At the time production was at 720,000 tons (15 percent of the global total), and 48,000 people were employed by the sector. With nationalization, production steadily declined until it fell to 257,000 tons in 2000 (see Figure 1) (Obasanjo et al., 2016). Although the government invested in infrastructure and development projects while operating the mines (approximately 30 percent of annual GDP between 1965 and 1982 (Government of Zambia, 2006)), copper prices began to fall (by 3.4 percent between 1973 and 2002), and production in the mines declined as capital investment in the mines was lacking. This, in combination with other factors such as the rise of oil prices (which increased import fees for copper importing nations) and a fall in copper prices, resulted in a drop in efficiency, and therefore outputs as technologies became outdated, as well as severe national debt ( $\$ 6.25$ bln in 1995). In the 1990s the mining sector contracted at the rate of 5.1 percent (Government of Zambia, 2006). The decline also affected the manufacturing and service sector, as many of the products developed and services were specifically designed to meet the needs of the mining industry (Government of Zambia, 2006). The mines are a trading centre, buying fuel, building supplies, food, cleaning, and security services from local suppliers. When the services and products needed by the mines decline, the town businesses suffer as well.

Kabamba (2014) contends that the Zambian government was pressured to privatize the mines by key donors such as the World Bank. After qualifying for the World Bank's Heavily Indebted Poor Country category (after the failure of the state-owned mines and the structural adjustment programs imposed by donors during the Cold War period), it was forced to choose between debt relief or control over its mineral resources. It chose to relinquish control of its mineral resources by privatizing them, and therefore qualified

\footnotetext{
2 This was done under the Mulungushi Reforms of 1968 detailing the government's plans of acquiring 51 percent or more equity in foreign-owned firms.
} 
for debt relief. In the late 1990s the mines were privatized once again and what is sometimes called the 'race to the bottom's began, with countries 'racing' to provide the most investor-friendly conditions. Production increased to over 700,000 tons in 2014, with foreign investments revitalizing the sector and employing 65,000 workers (Obasanjo et al., 2016).

While Zambia is primarily known for its deposits of copper in the Copperbelt province of the country, new mines have either opened or reopened in recent years, primarily in the North-Western province in Solwezi (also known as the New Copperbelt). Copper deposits are plentiful there, but of a lower grade or hidden deeper. Since privatization FDI has risen from $\$ 122 \mathrm{mln}$ in 2000, to \$1.6bn in 2015 (World Bank, 2015a). The current levels of production are just over 710,000 tons, with Kansanshi (80 percent owned by Canadian First Quantum Ltd) alone producing 226,674 tons in 2015 (First Quantum Minerals Ltd, 2016).

Today, Zambia is the second-largest copper producer in Africa, after the DRC, and the eighth largest worldwide (International Copper Study Group, 2016). In addition to copper, several other minerals are mined in the state including cobalt, gold, manganese, iron, emeralds and a variety of other gemstones, industrial minerals, as well as energy minerals such as uranium, coal, and hydrocarbons (Zambia Development Agency, 2015b). In terms of the contribution of mining to the GDP, in 2014 the World Bank (2016) estimates that the mining share of GDP amounted to 12 percent (up from 3.33 percent in 2001), and 28 percent of total revenue came from mining taxes. Mining constituted almost 78 percent of exports (of which 96.5 percent is from copper). In the previous year, 2013, mining accounted for 68 percent of exports (ZEITI, 2015).

Mines currently employ 1.7 percent of the population (ZEITI, 2015) and account for 61.7 percent of FDI (World Bank, 2016b). While the hope was that foreign investment in the mines would lead to a revival of the sector, producing employment and supporting the local economy, the effects have been minimal, despite the increase in production. By the time the mines were privatized in the 1990s, Zambia had gone from producing 15 percent of the global total of copper before nationalizing, to a mere 4 percent (Obasanjo et al., 2016). According to the Zambezi Report, the approximately 20-year period of nationalization and subsequent deterioration of the mines cost Zambia $\$ 45$ billion in production losses (Obasanjo et al., 2016). Currently, the state-owned ZCCM-IH maintains only a relatively small stake (approximately 10-20 percent) in the various mines, acting

\footnotetext{
${ }^{3}$ The competition in increasing tax exemptions and incentives given by African states to private sector investors in order to entice foreign investment in their country has been labelled the 'race to the bottom'.
} 
primarily as a silent partner (Kabamba, 2014). ${ }^{4}$ Mining has been clearly an important sector in the governing and development of Zambia.

Figure 1: Trends in Zambian Copper Production and Mine Employment

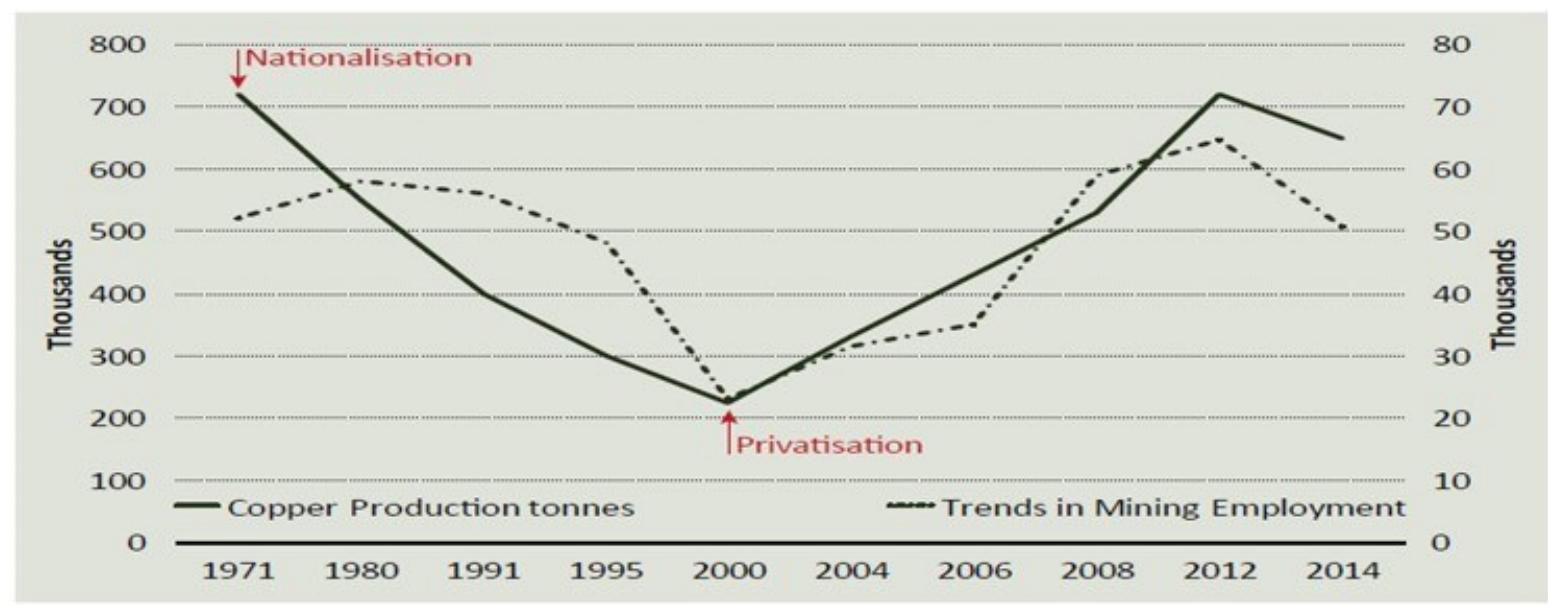

Source: Obasanjo et al. (2016)

\section{Contemporary Tensions}

As a result of the extent of social involvement and support provided by the state-owned mines in the Copperbelt (including health and education services), there has been some disenchantment over the lesser involvement of the newly privatized mines ${ }^{5}$. When nationalized, the mines were like small local governments onto themselves, providing their own schools, hospitals, sports facilities, roads, and other amenities for their employees. In addition, payment was frequently provided in rations. Privatization of the legacy mines came with some requirements of maintaining hospitals and schools in the communities, and services have been expanded beyond just mine employees, but the involvement of the mines in issues traditionally reserved for the state government, such as health or education, have declined. ${ }^{6}$ Some stakeholders implied that the legacy mines have not been delivering many of the services the communities have come to expect, and have in fact been giving other mines that are more involved in their communities a bad name. The negative perceptions of this decline may be aided by the lack of transparency in the Development Agreements between the government and the mines as to the responsibilities of each (International Council on Mining and Metals, 2014) as these are not publicly available.

\footnotetext{
${ }^{4}$ Interview, private sector stakeholder, Lusaka, Zambia, July/August 2016.

${ }^{5}$ Interview, NGO stakeholder, Lusaka, Zambia, July/August 2016

${ }^{6}$ Interview, NGO stakeholder, Lusaka, Zambia, July/August 2016
} 
However, despite the positive views of nationalized mines and their community services, ZCCM mines have also had very negative effects. For example, the city of Kabwe in Zambia has been contaminated by lead from the local, government-owned lead mine and smelter, and continues to be problematic despite the fact that the mine has been closed since 1994 due to the lack of clean-up efforts 7 . Other complaints have been surrounding the health and safety of miners particularly in Chinese-held mines in Zambia. Workers who complain are allegedly fired, or threatened with loss of pay or employment. In 2005 an explosion killed 46 Zambians at a Chinese-owned explosives manufacturing plant in Chambishi. With riots over work conditions following in the year after, at least five miners were shot according to a Human Rights Watch report (2011). In fact, the previous elections in 2006 and 2011 were influenced by these events, with anti-Chinese sentiments featured prominently in election campaigns. Other complaints have been made due to relocation of communities by the Kalumbila mine, as well as the increasingly acidic environment causing health issues around the Mopani mine (Mis, 2015).

Displacement of communities with inadequate compensation, as well as environmental degradation and pollution are all issues which have caused tension, although these complaints seem infrequent by comparison to other African states. However, the view that the mines are getting much more out of the investment than the people of Zambia persists, and there is some discussion of mines smuggling copper or various minerals out of the country without paying taxes on them, or declaring lesser values and therefore paying lower taxes ${ }^{8}$. These accusations have been denied both by the mines and, according to the International Council on Mining and Metals (2014), are highly improbable. Despite these negative connotations, most stakeholders interviewed expressed a clear appreciation for the importance of mining, and copper in particular, for the economy and development of Zambia.

While there is some resentment toward them, the mining companies insist that they are committed to the communities in which they work. The mines, particularly those in the New Copperbelt, have broad CSR programs which include a focus on women's empowerment, gender-based violence, education, as well as skills training. For example, Kansanshi supports the creation and evolution of Community Banks led by women"; Mopani has invested in creating highly skilled professionals through the vocational training at the centre in Mulufira (Daily Nation, 2016). Around the Sentinel mine (a \$2.1bn

\footnotetext{
${ }^{7}$ Lead toxicity levels of up to $300 \mathrm{ug} / \mathrm{dL}$ have been found in Kabwe children. By comparison the average blood levels in the US are $10 \mathrm{ug} / \mathrm{dL}$, with poisoning symptoms occurring at $20 \mathrm{ug} / \mathrm{dL}$ or above. Amounts of $120 \mathrm{ug} / \mathrm{dL}$ often result in death. For more information, please see www.blacksmithinstitute.org.

${ }^{8}$ Based on information acquired during interviews done with stakeholders in Lusaka, Zambia in July and August 2016 and (International Council on Mining and Metals, 2014).

${ }^{9}$ Interview, private sector stakeholder Lusaka, Zambia, July/August 2016.
} 
investment by First Quantum Minerals) FQM built the town of Kalumbila. The town is designed to outlive the mine, with a strong industrial and business focus.

The legally binding Development Agreements (DA) negotiated between the government and the mines lay out all the conditions and responsibilities of the mines, as well as the government for the duration of the Agreement. Such DAs are the result of careful negotiation and planning for 20 or more years ahead by the corporations involved in mining due to the high upfront costs and long payback periods. Much of the current tension and distrust between the industry and the government is the result of the breach of these contracts by the government following changes in regulations that were contradictory to the development agreements, primarily related to the increase of taxes which affect the long-term investment plans of the mining companies ${ }^{10}$. The lack of transparency and secrecy around the DAs is visible also in other areas where the government has been cautious about which data is released to the public. According to Revenue Watch (2013), in global rankings of government effectiveness and budget openness in 2013, Zambia received a failing score, and only a partial score on reporting practices. Other disagreements are often around the layoffs mining companies announce during copper price downturns to save money, or during expansions and upgrades, with government threatening the mines with licence withdrawals and searches for new investors who will maintain the workforce (Hill, 2015).

\section{Natural Resource Governance Framework}

In 2005 the Government of Zambia began developing, through a consultative process, a long-term development plan for the country. The document - Zambia Vision 2030-was published in 2006 and aims at making Zambia a prosperous middle-income nation by 2030. The Vision was written with seven basic principles in mind: sustainable development; upholding democratic principles; respect for human rights; fostering family values; a positive attitude to work; peaceful coexistence; and upholding good traditional values (Government of Zambia, 2006). The document offers three development scenarios which include a baseline, preferred, and optimistic version. The objectives contained within the Vision according to the preferred scenario are: annual real growth of 6 percent (2006-2010), 8 percent (2011-2015), 9 percent (2016-2020), and 10 percent (2021-2030); maintenance of an inflation rate of 5 percent; reduction of the national poverty head count to below 20 percent of the population; reduction of income inequalities; provision of secure access to safe water sources and better sanitation facilities throughout the state; access to education for all; and, the provision of quality health care for all (Government of Zambia 2006).

${ }^{10}$ Interview, private sector stakeholder, Lusaka, Zambia, July/August 2016. 
In terms of economic goals, the Vision aims at creating a Zambia that is well integrated into the region, continent, and international system. It calls for a diversified, balanced, and strong industrial sector with strong and cohesive industrial linkages, a modern agricultural sector, and a productive and efficient service sector. With regards to natural resources specifically, the Vision calls for the ability to use resource rents to invest, adapt, and innovate, developing policies consistent with sustainable environment and natural resource management. More generally it also refers to the development and maintenance of the socio-economic infrastructure and a macroeconomic environment which supports growth (Government of Zambia 2006) The long-term Vision is complemented by, and operationalized through, five-year development plans and annual budgets. The current national development plan is a revised version of the sixth iteration ${ }^{11}$, officially called the Revised Sixth National Development Plan (2011-2016), and consultations have begun on the Seventh National Development Plan (2017-2021). While past development plans have focused on economic diversification away from mining, the Revised Sixth National Development Plan (RSNDP) has primarily looked at infrastructure, capital investment, job creation, human and rural development. The plan identifies six growth areas: agriculture, livestock and fisheries; Manufacturing; Energy; Construction; Tourism; and Mining. The Seventh National Development Plan 2017-2021 consultations are underway. Zambia has several ministries and institutional bodies which are part of the policy framework around the extractive industry. These include the Ministry of Mines, Energy and Water Development, the Zambia Revenue Agency (ZRA), the Ministry of Finance, and the Zambia Environmental Management Agency, to name the most actively involved. The Zambia Revenue Agency (ZRA) is key in financial regulations such as taxation schemes, the ZRA and the Ministry of Finance are often the most influential bodies in the government.

In addition to the ZRA, the Zambia Development Agency (ZDA) plays an important role in the promotion of economic and industrial development. The legislation surrounding the ZDA (the ZDA Act 2006) not only establishes the Agency, but also establishes a Trade and Industrial Development Fund, offers incentives for investors and Multi-Facility Economic Zones (MFEZs), among others (GRZ, 2006). The ZDA has a broad mandate which includes the promotion and facilitation of the development of micro and small businesses; the attraction and facilitation investment, including greenfield investment; the promotion exports; and the promotion of education and skills training to increase productivity.

\footnotetext{
${ }^{11}$ It was revised due to the change in government, aligning it more with the goals and priorities of the newly elected Patriotic Front regime led by President Sata.
} 
The ZDA can also declare an area to be a MFEZ. The MFEZs are meant to be special industrial zones with physical and administrative infrastructure designed to attract international investment ${ }^{12}$. However, based on input from private sector stakeholders, gaining permission to establish an MFEZ is extremely difficult as the government has been restrictive as to whom and when they offer such permits for reasons which are unclear. Other incentives offered by the Act include a zero percent tax rate for five years, exemption from customs duties for any investment over US\$500,000, with the caveat that any business investment over $\$ 10 \mathrm{mln}$ can qualify for additional incentives (GRZ 2006). In addition, the investors can apply for permission to run a bonded factory or warehouse, and business in a priority sector such as mining, or rural enterprises qualify for a customs exemption when acquiring machinery or equipment. Again, this has been rare and difficult in practice, since as with the MFEZ, the government has severely limited such exemptions. Both the private sector and the agency (Zambia Development Agency, 2015a) acknowledge that the incentive structure is unattractive. The ZDA has its own strategic plan, with the most recent version covering 2016-2020. The plan details the need to improve its focus on investor incentives.

In an effort to support the Vision 2030, the strategic plan identifies five areas on which the ZDA will focus on: job creation, enhanced local participation, MSME capacity building, non-traditional export development, infrastructure development, and promotion of local and foreign direct investment (Zambia Development Agency 2015). The agency's role is to provide a one-stop shop for foreign investors by providing information, assistance in business partner and site selection, provide administrative support and consult on available incentives, as well as arrange for meetings with government officials. It has, however, not been very successful thus far.

The Government has also enacted a Public-Private Partnership Act of 2009, creating the Public-Private Partnership (PPP) Unit to deal with all PPP projects. The unit deals with investments by the private sector in public infrastructure development and provision of services. It allows for the submission of both solicited proposals through public tender and unsolicited proposals. This may create new avenues for mining companies to collaborate with public organizations on projects of mutual benefit, thereby establishing better relationships between the private and public sectors.

Overall, the policy framework in Zambia has been vague on some, and silent on many other important points. The focus is rarely on local suppliers and manufacturers, despite local content provisions in the Mines and Minerals Development Act (MMDA) and

\footnotetext{
${ }^{12}$ Four MFEZs have been declared thus far, including Chambishi, Lusaka East, Lusaka South, and Lumwana; and two Industrial Parks - Ndola and Roma (ZDA, 2016).
} 
stakeholder consultations. There are critical linkages missing between policies, which could provide opportunities to strengthen local development and industrialization (Fessehaie and al., 2016). For example, the Zambia Public Procurement Act 2011 offers preferential treatment to local manufacturers. However it does not apply to the mining sector (Fessehaie and al., 2016). Other opportunities to include local businesses, whether in manufacturing or services, could also be leveraged by the government, which maintains its share of the mining companies through the ZCCM-IH (Fessehaie and al., 2016). However, as already noted, the ZCCM-IH remains a silent partner in these investments rather than actively participating and encouraging local businesses and the mines to work together, presumably because the government does not have the capacity to get involved in each mine in such detail. In addition, while activities such as those by the ZDA to establish industrial parks and MFEZs have been relatively successful in acquiring the interest of companies, they are rare and not aligned with other efforts such as skills training and education which are required to supply the necessary talent to maintain and further develop these successes, as companies struggle to employ skilled workers (Fessehaie and al., 2016).

Skills training and education are an area in which Zambia has not developed a coherent policy in several years (Fessehaie and al., 2016), with the budget allocated to the Ministry of Education and Science decreasing despite mounting evidence of the importance and lack of skilled graduates. In fact, in 2015 the education budget share of the overall budget was the lowest in six years (4.3 percent), lower than the SADC average of 17 percent and below the recommendations of the Dakar Framework, a UNESCO initiative which aimed at achieving Education for All by 2015. The budget assigned is also typically released with such delays that much of the money from the last quarter is never dispersed further increasing the financial burden (UNESCO, 2016). Additionally, 84 percent of the budget is allocated to salary-related costs (UNICEF, 2016). Presumably the decrease in the education budget is the result of an increased focus on other areas such as industry, infrastructure, and power. However, this has only strained the already struggling education system. Based on interviews with stakeholders, the general perception is that government has not been able to coordinate policy across ministries and priorities, to ensure that goals such as local content or development and industrialization can be met successfully.

The Zambezi Protocol (Obasanjo et al., 2016) ${ }^{13}$ argues that when consultations have been held, the government has often ignored the outcomes of these consultations with industry representatives, creating legislation and regulation based on political agendas, rather

\footnotetext{
${ }^{13}$ The Zambezi Protocol is a product of a dialogue between the Brenthurst Foundation and mining companies on the banks of Zambezi.
} 
than long-term development. Over the last few years, the instability of legislation affecting mining as well as the fact that DAs have not been honoured, has deterred investment in Zambia and caused some mines to withdraw investment plans for expansions ${ }^{14}$. In fact, Zambia has made 797 statutory changes affecting mines or related to the taxation of mines since 2008 (Obasanjo et al. 2016). This is likely due to the sudden change in leadership following the death of President Sata, as well as the varying prices of copper which might incline the government to make frequent changes in order to get the most out of the mining industry. Still other changes were made following unrealistic taxation laws under which the industry refused to cooperate. By comparison, the DRC, another large copper producer, has had a stable tax rate since $2002^{15}$.

The changes to taxation have been particularly frustrating for investors. Some of the changes include a new tax regime introduced in 2008 consisting of higher royalties and taxes, including a windfall tax. Shortly after, in 2009, a new tax rate was instituted, with an effective tax rate of 47 percent (World Bank, 2011). In 2011 a 6 percent turnover tax and a 30 percent corporate tax for mines was implemented. Several legacy mines the Copperbelt, however, continued to enjoy the original zero percent, which further increased tensions between the government and some industry actors. ${ }^{16}$ In January 2015 legislation was changed to eight percent turnover tax on underground mines and 20 percent Mining Royalty Tax (MRT) for open-pit mines. This new tax regime, according to the IMF the second-highest among major copper producing mines, caused further disagreements with the industry. The government eventually backed down with a new regime enacted eight months later with a nine percent royalty tax for open-pit mines and 30 percent corporate tax plus a variable tax of 15 percent above a specified profit threshold. Under this regulation, the utilization of tax losses was limited to 50 percent of taxable profits each year, with a limit of a carry-forward for tax losses of 10 years (Obasanjo et al., 2016). ${ }^{17}$ In some years, the largest mine in Zambia, Kansanshi, has been responsible for as much as 90 percent of the corporate tax paid in the country (Obasanjo et al. 2016).

Tense debates between industry and government led to a change once again in 2016. An amendment was made to the MMDA of 2015, introducing 30 percent corporate tax and a sliding royalty scale of four to six percent for copper; a five percent royalty for other base metals as well as energy and industrial minerals and a six percent mineral royalty for gemstones and precious metals (GRZ, 2015). This new legislation has lessened the tax burden on the mines struggling from the current low copper prices. However, due to the

\footnotetext{
14 Interview, private sector stakeholder, Lusaka, Zambia, July/August 2016

${ }^{15}$ Interview, private sector stakeholder, Lusaka, Zambia, July/August 2016

${ }^{16}$ Interview, NGO stakeholder, Lusaka, Zambia, July/August 2016

${ }^{17}$ Interview, private sector stakeholder, Lusaka, Zambia, July/August 2016
} 
fact that the new regulation is less progressive than those in the past, the government will not receive as much in return when copper prices rise again (Manley, 2016). The uncertainty along with delays by government in VAT repayments on exports have resulted in the cancellation of new investment by mines, from $\$ 1.5$ bn projects by FQM, to projects by Glencore estimated at $\$ 800 \mathrm{mln}$ (Jamasmie, 2014).

While Zambia appears to be struggling with finding the perfect legal solution, several interviewees from regional organizations noted that despite international agreements on sharing expertise (for example with Australia), Zambia has implemented few if any of the suggested policies. ${ }^{18}$ The respondents also seemed to agree that the ministries with which a potential foreign investor in mining needs to work with and the procedures required are not coordinated through one ministry, but rather require the investor to deal with each individually. However, the Zambian Revenue Agency (ZRA) and Ministry of Finance is perceived as having the most influence, even in matters not directly related to taxation. The lack of coordination has also led to some confusion within the ministries, whereby for example an exploration permit was issued for a national heritage site in error, as other ministries were not consulted. ${ }^{19}$ Underscoring these perceptions is the Ease of Doing Business index by the World Bank in which Zambia fell to rank 97 this year, compared to 91 in 2015. The areas which the index marked as decreasing ease of doing business this year were the starting of a business, getting electricity, resolving insolvency, and, the topic most detrimental to Zambia's score-trading across borders (a drop of 42 points) (World Bank, 2016a).

The government has also not implemented specific policies on Corporate Social Responsibility (CSR) or detailed local content regulations. CSR projects remain voluntary and uncoordinated, although according to the Mines and Mineral Development Act 2015 companies have to sign a development agreement which includes items on local content, skills and training of nationals, and the promotion of local business development before beginning operations (GRZ 2015, sec. 32). The expectation by both the government and the people is often that the agreements will provide for a number of community services from health to education and infrastructure development, but companies do not feel responsible for certain services which should be the responsibility of the government, such as the maintenance of hospitals or universities, or the construction of public roads, which creates tension as well. ${ }^{20}$ That being said, theoretically all companies eventually have to negotiate with the community leadership (usually the traditional chief plays the role of the intermediary) in order to obtain written consent to purchase or lease land

\footnotetext{
18 Interview, IGO stakeholder, Lusaka, Zambia, July/August 2016

19 Interview, academic stakeholder, Lusaka, Zambia, July/August 2016

${ }^{20}$ Interview, private sector stakeholder, Lusaka, Zambia, July/August 2016
} 
which is owned by traditional authorities. ${ }^{21}$ This typically means that community development agreements (CDAs) are negotiated and signed between the company and community. However, it is up to the negotiators (primarily chiefs) from the community to determine whether the deals they make with the mining companies are in fact fair. Free, Prior and Informed Consent requires informed consent yet the knowledge needed to provide informed consent is in no way imparted uniformly across communities. Some chiefs who are well educated, or come from mining communities, often are more knowledgeable in the subject matter and are able to negotiate better. Therefore, informed consent varies significantly from community to community.

One potential way to address this gap would be for the government to offer capacitybuilding workshops to all communities on negotiation with mines on a regular basis. However, the government is already having great difficulties providing the necessary oversight to monitor and enforce its regulations in an efficient and effective manner. Efforts continue to align the Zambian mining acts and regulations to the African Mining Vision (AMV). As per the AMV action plan, Zambia has initiated the renegotiation of contracts or development agreements, it is in the process of fine-tuning the fiscal regime. Some of the activities that require further enhancements are capacity building for officials involved in negotiations and monitoring, strategies for investments of rents, as well as ensuring the legislation such as the MMDA are less vague, including that local communities benefit from the mineral resources mined in their area. Zambia's 2030 Vision includes a plan for improving geological and mining information, but it has not yet been undertaken. The local content provisions in the MMA are also minimal. The limited focus on skills training and education mentioned earlier in the report are a concern, as the AMV identifies this as an important accomplishment for the success of the economy. Another aspect identified by the AMV, the support of ASM, has also lagged in Zambia with many miners unable to obtain technical or financial assistance needed for their businesses to flourish. In terms of inclusiveness of the sector, transparency remains a worrying issue with regards to the development agreements between the government and the mining companies in particular. With regards to environmental regulations, Zambia is well represented by the Zambian Environment Agency, however, lacks the ability to monitor the private sector. Thus, while many steps have already been taken to implement and strengthen policy based on AMV recommendations, much work remains. Zambia also joined the EITI as a candidate country in 2009 and became compliant in 2012 (ZEITI, 2015). To maintain broader oversight of, and transparency in, taxation and mineral export, the government is in the process of introducing a new software systemthe Mineral Value Chain Monitoring Project (MVCMP). The project, supported by

\footnotetext{
${ }^{21}$ While this would normally be the case, based on an interview with a private sector stakeholder, the negotiation for land ownership can be 'hijacked' by the Government, if it so desires.
} 
Norway (Royal Norwegian Embassy, 2015), has brought together several ministries, including the Ministry of Mines and Mineral Development, the Zambia Bureau of Standards, the Central Statistics Office, the Road Development Agency, the Road Transport and Safety Agency, and the Patents and Companies Registration Authority. The new online monitoring system will systematically collect all required information from the mines and make it available to all government agencies that require such access, while also providing more transparency for the general public. Nine mines are currently using the prototype (MVCMP, 2016). The project is expected to conclude in 2018.

While all these initiatives involving transparency in revenue are laudable, and the Zambian government has maintained democracy and political stability in the state, little transparency in terms of government spending is available. Corruption is still frequently present in Zambia ${ }^{22}$, for example in the form of favours or monetary compensation for the expedition or guarantee of approval for a variety of issues the private sector may request, as well as vague justifications and secrecy around detailed budget plans ${ }^{23}$, the transparent oversight and monitoring of expenditures might offer opportunities to enhance accountability and democracy.

\section{Political Economy and Diversification}

Diversification is thus a must, to ensure that people are successfully employed in other areas and have transferable skills. The hope was that the mining companies would stimulate the local economy through value addition. However, many mining companies prefer to beneficiate their minerals in other locations. In some cases, the reasons are related to the fact that the company does not beneficiate, but sells raw materials to its customers, and thus has no interest in such investments. In others, lack of skills and education is an important limitation, despite the fact that all mining companies provide vocational training and schooling in their areas ${ }^{24}$. However, the lack of value addition and beneficiation operations locally means that corporations create 'enclave economies' which are not in fact an integrated part of the larger state economy of the country they are located in (Kabamba, 2014). The large corporations that own mines have already integrated value chains which are borderless and span across all their investments. ${ }^{25}$ They often prefer to work with global suppliers who have established partnerships with manufacturers from around the world and can provide for a large number of the mine's needs in one order. This means that even if domestic firms are available to manufacture

\footnotetext{
22 In fact, it has been suggested that the recent closure of the Norwegian Embassy in Lusaka has been in part related to the corruption and irresponsible management of public resources by GRZ (News24, 2016)

${ }^{23}$ Interview, private sector stakeholder, Lusaka, Zambia, July/August 2016.

${ }^{24}$ Interview, private sector stakeholder, Lusaka, Zambia, July/August 2016

${ }^{25}$ Interview, Lusaka, Zambia, 2016
} 
certain products, they may be passed over or the mine may not know that such even exist as it works with its regular supplier. Creating an environment in which beneficiation would be possible locally depends on the government implementing legislation with incentives for small and medium-sized businesses in Zambia, as well as supporting education in particular, to promote the creation of a skilled workforce ${ }^{26}$.

Backward linkages are the most promising avenue for the promotion of the local economy, but have been hampered by certain policies and regulations. For example, up until very recently, Zambia had foreign exchange controls (SI 33 of 2012, revoked in 2014) in place, which did not allow the use of a foreign currency in any transactions between actors domiciled in Zambia. Initially designed to aid the waning kwacha, these controls had the additional effect of increasing business costs and uncertainty due to the extra transaction costs and currency volatility (International Council on Mining and Metals, 2014). The Zambian Government is also severely understaffed, although its cabinet is one of the largest in Africa-it has 30 ministers (until very recently it has 20 ministers and 47 deputy ministers (Hobbes, 2013)). This amounts to high costs for salaries of senior-level politicians, fewer actual civil servants to administer, audit, and oversee government activities, and with a population of 75 percent below the poverty line (UNICEF, 2015), very little tax income other than from the mines. The government lacks funds and capacity, both in terms of human resources and technical skills. Patronage and corruption remain common.

Other obstacles include the limitations in power supply (particularly for forward linkages in which large amounts of electricity are needed for the beneficiation of minerals), a weak financial sector which is unable to provide businesses with large enough loans ${ }^{27}$, and in some cases lack of new equipment, skills, reliability, flexibility, and ability to adhere to minimum industry standards. The inability of the financial sector to offer loans to small businesses at attractive interest rates is a serious concern. Currently banks invest primarily in government bonds rather than taking on the risk of investment in private businesses. According to the Bank of Zambia (2016), the current overnight interbank interest rate is 18.45 , and the overnight lending facility rate as high as 25.5 percent. The overnight rates are the lowest available interest rates charged by the central bank when a financial institution borrows money. According to the press, at the end of May 2016, despite better liquidity conditions, commercial banks maintained high interest rates for personal loans, varying between 30 and 40 percent (Lisulo, 2016). With high interest rates like these, the banks are extremely cautious of approving loans, and often cannot offer large loan amounts due to the fact that the levels of kwacha are low and they lack

\footnotetext{
${ }^{26}$ Interviews, private sector stakeholder, Lusaka, Zambia, July/August 2016

${ }^{27}$ Interview, non-governmental organization stakeholder, Lusaka, Zambia, July/August 2016
} 
liquidity. The major advantage for mining companies to employ local suppliers lies in the fact that they should be able to deliver the products quickly and with little transport costs. However, due to the financial challenges they encounter, access to financing to operate production infrastructure and maintain large stocks of products and parts to ensure quick delivery is a major challenge (Fessehaie, Rustomjee, and Kaziboni, 2016).

In terms of value addition, the International Council on Mining and Metals (2014) estimates that procurement of imported goods is almost entirely made through Zambian companies, but only 5 percent of industry goods procured for the purpose of mining are locally manufactured. In an effort to promote business relationships with local suppliers, mines have created programs and employed staff to assist businesses in tendering, marketing, or developing technical capacities, among others (International Council on Mining and Metals, 2014). For example, Kanshansi offers a development program in which it trains emerging contractors, offers business development workshops for SMEs, and continually explores possibilities for local manufacturing.

The government has also instituted some local content regulations-according to the MMDA of 2015 para 20, a mining company has to give preference to materials and products made in Zambia, as well as Zambian contractors, suppliers, and service agencies. While this is difficult to enforce, the mines adhere to this stipulation not only because it is the law, but also because it is cheaper and more convenient for them to deal with local companies if they are available. The legislation also specifies preferential employment to citizens and the implementation of training programs in technical and managerial skills for Zambians. In some cases, backward flow such as production of mill balls for the Kansanshi mine in Solwezi, has been supported by the mines through their local development programs. ${ }^{28}$ Several services and organizations from outside the government and the mines have also created local content programs to work with local businesses, including the Zambian Mining Local Content Initiative, or the Private Enterprise Programme, Zambia. While these initiatives have been successful ${ }^{29}$, their effects are only slowly influencing local business development. Such initiatives by the mining sector and other agencies should be coordinated and integrated into broader national development plans to stimulate the local economy and support the growth of local businesses (ILO, 2015).

While all these developments are positive, other legislation continues to restrict local content. For example, the Zambian national tariff schedule discourages investment in

\footnotetext{
${ }^{28}$ Interview, private sector actor, Lusaka, Zambia, July/August 2016

${ }^{29}$ For example, the Private Enterprise Programme Zambia was recently applauded by the Zambian Ministry of Commerce, Trade and Industry for assisting small businesses in participating in supply chains of larger businesses (PEPZ, 2016).
} 
local assembly operations, as it requires the payment of duties on the import of spare parts and components. The remedy for this calls for a more complex design of the tariff schedule, which could increase duties on parts which can be bought locally, but lower them on those which are locally unavailable yet needed to assemble equipment in Zambia (Fessehaie, Rustomjee, and Kaziboni, 2016). Such a structure would call for increased monitoring which may be difficult for the institutions charged with this responsibility due to the lack of human and financial resources.

Stakeholders, particularly those from organizations which take a broader regional or continental view, have indicated that there are opportunities for beneficiation and value addition on a regional scale. Particularly countries belonging to such regional organizations as COMESA, SADC, or EAC would benefit from collaborating in a way that offers services, products, and skills to mining companies in close proximity to their enterprises, but also spreads the responsibility and investment in such a value chain across several countries with each building on its own strengths to contribute. With the SADC being the largest (by far) market for mining equipment in the world, the potential is enormous. ${ }^{30}$

\section{Conclusions}

Zambia is currently facing an economic crisis caused by falling copper prices and electricity shortages. Lower demand from China, Zambia's biggest export market, budget deficits, and low agricultural output over the last year due to drought have kept investors at bay. Based on weather predictions, pressures on public spending due to the election in 2016, and the low likelihood of copper prices increasing, economic growth is expected to be sluggish (AfDB, OECD, and UNDP 2016).

The government is already prioritizing many of the most important areas for economic growth and development. Zambia is seeking to diversify its economy due to its overreliance on natural resources with specific goals enshrined in the National Vision. However, Zambia's Vision 2020 is overwhelmingly focused on macroeconomic factors, with education barely mentioned. This reflects the trend of decreasing the budget available for education in Zambia. Learning from other resource-rich countries in the region and outside, such as Australia or countries in the Middle East, there are certain lessons to be extracted, particularly on prioritizing education.

${ }^{30}$ Interview, IGO stakeholder, Lusaka, Zambia, July/August 2016 
By investing in its population, the state will have more skilled professionals both to create local businesses as well as an easily accessible workforce for companies entering Zambia. Additionally the government has to ensure that all policies and regulations are coordinated to support local content, SMEs, and public-private partnerships. In terms of the tax regime, stability and predictability, also for incentives, as well as more transparency are fundamental.

Zambia remains a perfect case study for natural resource governance due to both its long tradition of mining and its experience in nationalization and privatization. It is, furthermore, a politically stable and peaceful state, despite the rampant poverty and corruption issues. As such, foreign investment in Zambia is significant, and therefore policies affecting the private sector are key in promoting continued development. Natural resources have long been Zambia's primary income-producing sector, understanding governance around the sector and how it interacts with other sectors such as education, offers an important view into the broader vision, values, and priorities of the state government.

\section{References}

AfDB, OECD, and UNDP. 2016. "African Economic Outlook 2016."

Bank of Zambia. 2016. “Bank of Zambia.” Retrieved from http://www.boz.zm/. Lusaka.

Blacksmith Institute. 2016. "Kabwe Lead Mines." Retrieved from http://www.blacksmithinstitute.org/projects/display/3. Accessed September 11, 2016.

Central Statistical Office. 2014. "Zambia in Figures: 1964-2014.” Lusaka.

Daily Nation. 2016. “Mopani Builds US\$21m Training Centre in Mufulira." Daily

Nation, May 23. Retrieved from https://zambiadailynation.com/2016/05/23/mopanibuilds-us21m-training-centre-in-mufulira/. Accessed on September 10, 2016.

Fessehaie, Judith, Zavareh Rustomjee, and Lauralyn Kaziboni. 2016. “Mining-Related National Systems of Innovation in Southern Africa: National Trajectories and Regional Integration." 2016/84. Working Paper. Helsinki.

First Quantum Minerals Ltd. 2016. “Kansanshi Mine." Retrieved from http://www.firstquantum.com/Our-Business/operating-mines/Kansanshi/. Accessed on September 9, 2016.

Fraser, Alastair, and John Lungu. 2007. "For Whom the Windfalls? Winners and Losers in the Privatisation of Zambia's Copper Mines." Retrieved from 
http://www.liberationafrique.org/IMG/pdf/Minewatchzambia.pdf. Accessed on August 10, 2016.

Government of Zambia. 2006. "Zambia Vision 2030: A Prosperous Middle-Income Nation By 2030." Lusaka.

GRZ. 2006. Zambia Development Agency Act. Zambia. . 2015. Mines and Minerals Development Act. Zambia.

Hill, Matthew. 2015. “Glencore Can't Fire Workers at Zambian Unit, President Says.” Bloomberg, November 4. Retrieved from

http://www.bloomberg.com/news/articles/2015-11-04/glencore-can-t-fire-workers-atzambian-unit-president-says. Accessed on August 1, 2016.

Hobbes, Michael. 2013. "Why Is Zambia So Poor?" Pacific Standard, September 12. Retrieved from https://psmag.com/why-is-zambia-so-poor-f44dfeedd5ed\#.hbjee6y0t. Accessed on February 2, 2017.

Human Rights Watch. 2011. “'You'll Be Fired If You Refuse' Labor Abuses in Zambia's Chinese State--Owned Copper Mines." Retrieved from https://www.hrw.org/report/2011/11/04/youll-be-fired-if-you-refuse/labor-abuseszambias-chinese-state-owned-copper-mines. Accessed on August 2, 2016.

ILO. 2015. "ILO Policy Note: Inclusive Business Practices in Africa's Extractive Industries." Geneva.

International Copper Study Group. 2016. “The World Copper Factbook 2015.” Lisbon. International Council on Mining and Metals. 2014. "Enhancing Mining's Contribution to the Zambian Economy and Society." Mining: Partnerships for Development. London. Jamasmie, Cecilia. 2014. “First Quantum Warns Zambia Tax Hike Will Cost Jobs Investment Drop." Mining. com. Retrieved from http://www.mining.com/firstquantum-warns-zambia-tax-hike-will-cost-jobs-investment-drop-13778/. Accessed on February 2, 2017.

Kabamba, Claude. 2014. "Myths and Mining: The Reality of Resource Governance in Africa." 8. Open Debate. Johannesburg. Retrieved from http://www.osisa.org/opendebate/economic-justice/regional/myths-and-mining-reality-resource-governance-africa. Accessed on July 3, 2016.

Kruger, Anita. 2013. "Mining in Zambia: A History Lesson." MACIG. Retrieved from https://macigindaba.com/2013/09/20/mining-in-zambia-a-history-lesson/. Accessed on July 10, 2016.

Limitlaw, D. 2011. “Nationalization and Mining: Lessons from Zambia." The Journal of the Southern African Institute of Mining and Metallurgy, 111: 737-39. 
Lisulo, Stuart. 2016. “Banks Maintain High Lending Rates." The Post, May 20. Retrieved from http://www.postzambia.com/news.php?id=18108. Accessed on July 10, 2016.

Manley, David. 2016. "Zambia's New Mining Tax Regime May Fail the Test of Time I Natural Resource Governance Institute." NRGI Blog. Retrieved from

http://www.resourcegovernance.org/blog/zambias-new-mining-tax-regime-may-failtest-time. Accessed on July 1, 2016.

Mis, Magdalena. 2015. “Women Pay the Price for Zambia Mining Expansion.” Reuters, September 14. Retrieved from http://www.reuters.com/article/us-zambia-miningwomen-idUSKCNORF02D20150915. Accessed on August 1, 2016.

MVCMP. 2016. "Monitoring Mining and Mineral Value Chain from Exploration to Exportation." MVC. org. Retrieved from http://www.mvc.org.zm/?p=95. Accessed on February 2, 2017.

News24. 2016. "Norway Shuts down Embassy in Zambia." News24. Retrieved from http://www.news24.com/Africa/News/norway-shuts-down-embassy-in-zambia20160415. Accessed February 2, 2017.

Obasanjo, Olusegun, Greg Mills, Dickie Davis, Dianna Games, and Lyle White. 2016. "The Zambezi Protocol: Result of a Dialogue on Natural Resource Policy in Africa." 7/2016. Brenthurst Discussion Paper. Johannesburg.

PEPZ. 2016. "MINISTRY OF COMMERCE APPLAUDES PEPZ." News. Retrieved from http://www.pepzambia.com/news/48-ministry-of-commerce-applaudes-pepz.html. Accessed on June 20, 2016.

Revenue Watch Institution. 2013. "The 2013 Resource Governance Index," no. September 2012: 1-2. www.revenuewatch.org/rgi.

Royal Norwegian Embassy. 2015. “The Mineral Value Chain Monitoring Project.” Lusaka, Zambia. Retrieved from http://www.norway.org.zm/News and events/norwayzambia/Budget-support-andfinancial-management-including-Tax-for-Development/Monitoring-the-productionprocessing-and-exports-of-copper-and-other-minerals-The-Mineral-Value-ChainMonitoring-Project-/\#.V9YKgZg. Accessed on July 15, 2016.

UNESCO. 2016. "Zambia UNESCO Education Policy Review." 2016. Retrieved from https://www.google.com/url?sa=t\&rct=i\&q=\&esrc=s\&source=web\&cd=1\&cad=rja\&uact= 8\&ved =0ahUKEwjctsXqyPLRAhXnsVQKHeIKCWcQFggcMAA\&url=http $\% 3 \mathrm{~A} \% 2 \mathrm{~F} \% 2 \mathrm{~F}$ unesdoc.unesco.org\%2Fimages\%2F0024\%2F002464\%2F246408e.pdf\&usg=AFQjCNF3x0 PGPYI1FCn0VL zMmNc6PrvzA\&sig2=ShX4BsXyRtOr7n-NWomY6Q. Accessed on December 19, 2016. 
UNICEF. 2015. “The World's Children 2015 Country Statistical Tables.” Retrieved from http://www.unicef.org/infobycountry/zambia statistics.html. Accessed on February 2, 2017.

- - - 2016. "Zambia Education Budget Brief: Review of Budget Performance and 2016 Allocations." Lusaka.

World Bank. 2011. “What Would It Take for Zambia's Copper Mining Industry to Achieve Its Potential?" Retrieved from http://documents.worldbank.org/curated/en/461971468170956129/pdf/623780ESW0Gray 0e0only0900BOX361532B.pdf. Accessed on August 31, 2016.

- - - 2015a. "Global Economic Prospects." Retrieved from http://www.worldbank.org/en/publication/global-economic-prospects/data?region=SST. Accessed on February 2, 2017.

- - - 2015b. “World Development Indicators." Retrieved from http://data.worldbank.org/indicator/DT.ODA.ODAT.CD/countries/BI?display=graph. Accessed August 30, 3016. - - - 2016a. “Ease of Doing Business Zambia." Doing Business. Retrieved from http://www.doingbusiness.org/data/exploreeconomies/zambia/\#trading-across-borders. Accessed on August 30, 2016.

- - - 2016b. "The Mining Investment and Governance Review (MinGov) Zambia Final Report." Washington, DC.

Zambia Development Agency. 2015a. “2016-2020 Strategic Vision.” Lusaka.

- - - 2015b. "Mining Sector Profile." Lusaka. Retrieved from http://www.zda.org.zm/?q=download/file/fid/167. Accessed on February 2, 2017.

ZDA. 2016. “Multi-Facility Economic Zone (MFEZ).” Zambia Development Agency Website. Retrieved from http://www.zda.org.zm/?q=content/multi-facility-economiczone-mfez. Accessed September 10, 2016.

ZEITI. 2015. "Seventh Report of the Zambia Extractive Industries Transparency Initiative (ZEITI)." Lusaka, Zambia.

\footnotetext{
${ }^{1}$ Karolina Werner is a researcher at the Centre on Governance, University of Ottawa and a PhD candidate at the Balsillie School of International Affairs, Wilfrid Laurier University.

2 This research was supported by the Centre on Governance in collaboration with the Qatar Foundation's National Priority Research Program (NPRP)-funded project, entitled "Governance of Natural Resources in Africa: Advancing a Qatari Perspective and Economic Diversification”. NPRP No.: 6-1272-5-160.
} 